Nico Koopman

Nico Koopman is Dean of the Faculty of Theology, and Director of the Beyers Naudé Centre for Public Theology at the University of Stellenbosch. E-mail:nkoopman@sun.ac.za.

\title{
A prophet for dignity? A theological perspective
}

A prophet for dignity? A theological perspective

This paper portrays the work of Adam Small as prophetic work. Three dimensions of the practice of prophetic speaking are described, namely prophetic envisioning, prophetic criticism and prophetic policymaking. Small's work is described in terms of these categories. During the struggle against apartheid and during the current quest for a new society of dignity, justice and freedom, Small's prophetic envisioning, prophetic criticism and self-criticism and his prophetic policymaking discourse is of immense importance. Amidst our struggle to build a new society his prophetic envisioning gives hope and inspiration. Amidst our anger about so many wrongs in society and the non-fulfilment of the vision of a new society, his prophetic criticism and self-criticism gives fortitude and courage. Amidst reservations about participation in complex and sophisticated public debates, public opinionformation processes and public law-making processes, his prophetic policymaking discourse gives illumination and perspective. Keywords: Adam Small, anti-apartheid writing, dignity, prophetic speaking, public opinion-formation.

\section{Introduction}

It is not strange that theologians engage with the work of Adam Small. He consistently relates the plight and struggle of oppressed and marginalised people with faith in God. Let me cite a few examples of the direct engagement of theologians with him. In the Netherlands the German theologian, Volker Küster, borrows from his work and specifically from his conviction that writers, poets and art are indispensable for the achievement of reconciliation in South Africa. A few years ago the South African theologian, Dirkie Smit, uses his famous poem "What about de lô?" (What about the law?), in a paper at the University of the Western Cape on the relationship between morality and law. In 1972 theologians were interested in the perspectives of Adam Small. He was therefore invited to address a conference of the Black Theology Project of the University Christian Movement (Small, "Blackness"). Theologians often discussed the theological nature of his work.

I remember how Small addressed us as theology students at the University of the Western Cape during our reflections on the role of students in the struggle against apartheid. Small's works inspired me when I was in primary school, when I was a student at Western Cape University and during decades as pastor and theologian. To write this article is therefore a privilege, and an exercise in expressing formally and in a structured way what I had practised informally and unstructured until now. 
In all the years of reading Small I experienced that this poet and artist, intellectual and opinion-maker, acknowledges, affirms and actualises my dignity. In my childhood days in the politically conservative Northern Cape his work helped me to resist the effects of the apartheid ideology to make me feel inferior to white people and superior to black people. During my student days his work strengthened and encouraged us to resist apartheid and injustice. And during my years as pastor and theologian, i.e. the last years of apartheid, the years of transition to democracy, and the years of building a new society, I was inspired by the work of Adam Small. It is especially these last years that call for attention here. This paper investigates the relevance and significance of his work for the building of a democracy where dignity is actualised and where justice and freedom are effectuated.

Here I portray his literary and nonfiction writing as works that seek the fulfilment of the dignity of all human beings. This dignity is actualised through prophetic discourse. Small's work is therefore described as prophetic. His contributions in various genres like poetry, newspapers columns and presentations at academic conferences, can rightly be described as prophetic. It will be demonstrated how his work reflects various modes of prophetic speaking, namely prophetic envisioning, prophetic criticism as well as prophetic opinion-formation and policy-making. Each of these interdependent modes of prophetic speaking is described separately, and in every instance it is demonstrated how Small reflects these modes of prophetic speaking. This analysis will pave the way for determining the relevance of his writing in the building of a democratic society where dignity is acknowledged, affirmed and actualised.

\section{Prophetic envisioning}

The US theologian, James Gustafson, argues that the prophet has the twofold task of envisioning and criticising. Prophets as visionaries, according to Gustafson (13-14), portray an alluring vision of the future. They see a new world in which the strife and suffering that we currently experience will be overcome. This vision may indict the contemporary broken reality, but its main function is to allure and attract people to act concretely and to attempt to approximate the vision. The prophet as visionary uses utopian language, symbols, analogies, similes, and metaphors that move us. Their speeches are not technical moral arguments or policy statements. Listeners are moved by aspects like passion of the speaker's voice, the cadences and figures of speech, many drawn from the Bible, that are employed, and also the moral authenticity of the speaker. Such visionary language moves us from indignation with the present to aspiration for the future.

The Brazilian Reformed social scientist and theologian, Rubem Alves, offers a strong plea for prophecy as envisioning. He calls for the task of prophecy as 
envisioning, specifically in so-called post-liberation societies. He talks about societies that had struggled against oppression, but who do not fulfil the vision of an alternative society years after the victory from oppression has been achieved. Alves (183) speaks, in fact, about societies that had become democracies, but had forgotten the vision of a liberated society, the vision that strengthened them during their struggle for liberation.

He writes remarkably about the disappointments that follow various liberation experiences. After World War II the expectation was that the two handmaidens of reason, science and technology, could bring about peace, harmony and prosperity in the world. What followed however, was an era of various wars, especially the socalled Cold War, the international arms race, the growing gap between rich and poor among and within nations, hunger, exploitation, oppression, and political and economic imperialism.

The revolutionary movements of the 1960s were not followed by periods of harmony and prosperity (Alves 183-84). The frustration about the absence of "the new" in post-liberation contexts, indeed reminds one of the post-liberation context of the young democracy in South Africa, which came about in April 1994 when the first inclusive democratic elections took place. Although we are making good progress towards building a country where all may enjoy a life of prosperity and dignity, for millions of poor South Africans the promised new life remains elusive.

Alves pleads for the restoration and revival of creative imagination and the renewal of hope. This vision of hope is born amongst people who suffer, and not amongst those who enjoy prosperity and well-being, and are tempted to view their present as the best possible world. Hope and suffering function in tandem. "Those who live in the pain-delivering sectors of our society, however, even before they can articulate in speech the evil of this world, are already doing it by means of their inarticulate groans" (Rom. 8: 26). According to Alves (200-01) "this is the raw material the spirit takes unto Himself [...] this is the emotional matrix which is the beginning of the creative event. Suffering prepares the soul for vision. Personality refuses to take things as they are. It spreads its wings and the heart emigrates to the horizons of the future." Alves continues:

For creation to take place, suffering and hope cannot be separated. Suffering is the thorn that makes it impossible for us to forget that there is a political task still unfinished-still to be accomplished. And hope is the star that tells the direction to follow. The two, suffering and hope, live from each other. Suffering without hope produces resentment and despair. Hope without suffering creates illusions, naiveté, and drunkenness (203).

This hope and creative imagination bring forth a new, surprising creative event, which cannot be scientifically analysed, cognitively dissected and eventually duplicated (Alves 197-98). This hope is theological hope. It is Trinitarian hope. It 
looks forward and it looks back. It rests upon what had happened in the past and at what is happening in the present, specifically in God's acts of creation, and of recreation in Christ and renewal in the Spirit (Alves 198).

Alves (185-86), with an appeal to Nikolai Berdyaev and Martin Buber, argues that revolutionary movements had lead to frustrating outcomes since they focused too much on the wrong that they had to break down, and not on the good that they had to bring into being. Their euphoria about victory over evil soon disappeared because during their struggle against evil they did not adequately envision and embody the new reality. Through this grave negligence and omission they actually had paved the way for a society where the old would be repeated.

Alves offers a thorough analysis of this neglect and its consequences that has disturbing relevance for South Africa. His analysis challenges South Africans to remember the vision of a new, post-apartheid society that we had once adhered to. It is articulated in a document like the Freedom Carter and was voiced at the launch of the United Democratic Front in 1983. It was expressed in the South African Constitution of 1996, and shared by South Africans from all political, ethnic, religious and cultural communities. In the Bill of Rights, i.e. article 2 of our Constitution, this vision entails a society of dignity, equality, freedom, justice and equity. Various religious documents resonate with this vision of the type of society that South Africans want to strife for.

Without vision we shall perish. Faithful prophetic work entails, in these days of amnesia and forgetfulness, the public proclamation of the vision of a new society of justice and joy. This is the political task of the church, in the words of Alves (197):"If ours is not the harvest season, it may well be a time for sowing [...] In spite-and because-our tall trees have been cut down, our air polluted with fear, and our soil turned into a heap of refuse, a new seed must be planted: the seed of our highest hope."

Prophets remember the vision of a new society. They remember the future, the future of God, the future of the reign of God and its righteousness. And they remember the approximate manifestations of this vision in the life of Israel and the church. They remember the reality of the complete fulfilment of this vision of God in the person and work of Jesus Christ, who shall come again, and whose Spirit is at work in and through, and outside the church, to actualise this vision of justice, peace and joy for all.

Adam Small kept the vision alive of a new South African society. In his address to the theologians at the 1972 conference on Black Theology he spelt out the contours of this vision, articulating a vision of human dignity, non-racialism and justice for all (Small, "Blackness"). He described himself as "a black person". Blackness did not constitute an ethnic category for him. Blackness referred to a certain insight, a certain awareness. One might say blackness refers to the awareness of and identification with 
people who suffer dehumanization, injustice and oppression in their country of birth. It is the insight that 'black people' are not inferior to white people. Blackness emphasises the quest for the effectuating of the dignity of dehumanised people. Those who opposed apartheid did not want to be integrated into whiteness and white communities. They in fact rejected it. They wanted their dignity as black people to be affirmed. Moreover, they live by the grace of God, but not by the grace of whites. Black people are not there for the sake of whites. We are there. We are. He pleads for dignity as equality in worth and value.

Blackness therefore stood for dignity and justice and non-racialism. Small did not envision a South Africa of exclusion of anyone of its citizens, including white people. In line with the Freedom Charter of 1955 Small dreamt of a South Africa of which we can say that it "belongs to all who live in it". He insists that we have suffered long enough under white racism. We therefore cannot be racist in our blackness.

In two poems entitled "Exodus" and "Second Coming II" he expresses the hope and expectation that the new shall be born (Sê sjibbolet 13, 44). In "Exodus" he explains that our current patient suffering is indispensable for entering a new life of dignity and prosperity where there are plenty of grapes, water that is not bitter and manna from heaven, as well as our eternal garden like Eden, i.e. Paradise. "Second Coming II" describes the second coming of Jesus Christ, in an aeroplane at an airport. His followers at the airport complained at his press conference about his delayed return to earth after his ascension. Hereby he articulates a healthy impatience with the status quo and an appeal for the coming and intervention of Christ in the world of injustice to bring about a society of justice. In "Nkosi Sikelel iAfrika" he envisages a blessed world where every ox and nation flourishes (Sê sjibbolet 96).

Small's vision of a new society is a vision of hope. Amidst dehumanisation, injustice and oppression he envisaged a whole new world. He could not accept that the reality of oppression was the only possibility. He realised that something different was possible. Small helped us to hold on to the dream of a new South Africa where justice and peace reign supreme.

Prophets like Adam Small kept the dream alive of a new world. Since 1994 when democracy was born in our country, we worked hard to incarnate and embody this vision. The emphasis is rightly on policies, practices and institutions that enhance the actualisation of the vision. But our broken reality indicates that we cannot afford to forget the vision. The vision should be proclaimed loud and clear. If this does not happen we may forget where we come from and where we are heading. We should remember the thorn of our oppression, but we should also remember our vision as the star that guides and lures us to a new society. A re-appreciation of the work of Small might focus our attention and actions afresh on that cherished star that had enabled us to move out of slavery, and that will bring us closer to the promised land. 


\section{Prophetic criticism}

According to Gustafson the second dimension of prophetic speaking is that of courageous criticism. Besides annunciation, prophets have the task of denunciation. Besides the task of announcing the vision of a new society, prophets perform the task of denouncing the reality that is in conflict with the vision of a new society. The prophet as critic addresses what is perceived as the root of the problem (Gustafson 711). The 'problem' is not merely viewed as a matter of policies that are inadequate and wrong, but it is a matter of religious, moral and social waywardness. The critic names the devil that presumably underlies the various wrongs in society. Prophetic criticism gets to the roots of problems that pervade institutions and cultures, or that pervades the actions and behaviour of individual persons. On basis of statistical indicators and social analysis they expose the causes and roots of social and personal wrongs. They do not engage in detailed policy recommendations, and matters of strategy and tactics. The indictments of the prophet as critic construe the human condition in deep and broad proportions. And these prophetic indictments lead to conviction of guilt, and constitute a call to a fundamental repentance and a radical turn from unfaithfulness to faithfulness.

During apartheid the notion of 'apartheid as a heresy' was employed to expose the theological causes and roots of what went wrong in our society. The notion of 'empire' is currently employed to express what is going wrong in contemporary societies in local, regional and global contexts. The globalisation research project of the Evangelisch Reformierte Kirche in Germany and the Uniting Reformed Church in Southern Africa, which is hosted by the Beyers Naudé Centre for Public Theology at Stellenbosch University, offers a helpful definition of empire:

We speak of empire, because we discern a coming together of economic, cultural, political and military power in our world today, that constitutes a reality and a spirit of lordless domination, created by human kind yet enslaving simultaneously; an all-encompassing global reality serving, protecting and defending the interests of powerful corporations, nations, elites and privileged people, while imperiously excluding, even sacrificing humanity and exploiting creation; a pervasive spirit of destructive self-interest, even greed-the worship of money, goods and possessions; the gospel of consumerism, proclaimed through powerful propaganda and religiously justified, believed and followed; the colonization of consciousness, values and notions of human life by the imperial logic; a spirit lacking compassionate justice and showing contemptuous disregard for the gifts of creation and the household of life (Boesak et al. 2).

The definition of these two churches focuses on empire not only as specific nations, corporations, or institutions. It is deeper, wider and more inclusive than attempts to attribute the notion of empire only to such clearly definable institutions. It implies 
these institutions, but also unmasks the spirit, gospel and ethos that it is constituted and nurtured by, and that it in turn reinforces. This definition of empire helps to unmask the spirit of empire in the practices, policies, and institutions in all walks of life, on local, regional and global level. Moreover it helps to unmask the spirit of empire in the hearts of humans and in the life of churches as well.

Notions like empire are not famous. One often feels that it might be better to avoid such controversial and potentially divisive concepts. On the other hand, concepts like these enable us to pay attention and to become conscientised about what is going on around us and in us. These concepts shock in order to restore (in Afrikaans: hulle ontstel om te herstel). And prophets are called upon to, amongst others, shock in order to restore.

Prophetic discourse as prophetic criticism also entails self-criticism. For various reasons churches should engage in constructive self-criticism. We should, however, guard against a form of self-criticism that does have pacifying effects, a self-criticism that serves as excuse to terminate public involvement, because we are ourselves so very imperfect. What is required is self-criticism, which shows that we are aware of our sinfulness and fallibility as human beings. Because we are imperfect, sinful beings even our best efforts as churches might be contaminated. Without constructive selfcriticism we cannot speak legitimately in the world. We need to acknowledge that societal wrongs are present in our own ranks, e.g. sexism, misogyny, heterosexism, patriarchy, homophobia, nationalism, handicappism, ageism, ecocide, exclusion and exploitation.

Small's work indeed does disturb (ontstel) in order to heal (herstel). He voiced his criticism in various writings and poems. His writing challenged churches to do selfcriticism and to discern the spirit of, what is now called empire, in our midst. His poem "Doemanie" (lit. the Afrikaans title, dominee, of especially Reformed pastors) unmasks the luxurious lifestyle of some pastors amidst the poverty of their congregants (Kitaar 25). Unlike the prophets of biblical times like John the Baptist, some contemporary pastors live in wealth and riches. Unlike John they do not eat "locusts and wild honey" in the desert or clothe themselves with "the hide of camels". They rather live in palaces, drive "aeroplane cars", and eat sumptuously. He unmasks the spirit of empire manifested as consumerism and greed amongst church leaders.

In "Dankgabet vannie skollie" ("Thanksgiving of a gangster") he criticises hypocrisy amongst Christians (Kitaar 36). He unmasks the conflict between what we preach and what we practice. His challenge to churches to do self-criticism is also expressed in the poem entitled "Die Here het gaskommel" ("The Lord threw a dice"). This poem criticises the attempts to give divine legitimation for the wealth of some, and the poverty of others. God is portrayed as the One who threw a dice: For the rich the dice fell favourably; not so for the poor and suffering. Moreover, those who suffer are called 'children of Ham' who, according to the Genesis 9 narrative, did not protect 
his drunken and naked father Noah, and who was consequently cursed together with his progeny. Small employs irony to unmask the theological rationale for the suffering of many people.

Humour constituted a crucial dimension of his prophetic criticism. He uses humour in a liberating way to drive his point home. His poem "Oppie Parara" ("On the Parade", referring to the Grand Parade in Cape Town) portrays the humorous interaction of a so-called Koelie (i.e. South African of Indian origin) green grocer with a white female customer (Kitaar 32-33). In apartheid society where social interaction between males and females across the colour line was frowned up, and legally prohibited; where whites were viewed as superior to blacks, the white woman, as a representative figure of white power and unattainable sexuality, remains aloof and uptight in the face of the vendor's humorous (and sexually suggestive) sales pitch. He tells her of "his little tents that are full of joy", but she remains "sour like vinegar"; he tells her about the "figs / swollen from top to bottom", playing on the Afrikaans colloquialism for the female genitalia, vy, but "don't blush Madam we have the leaf [to go along with it]." As she scolds him and walks away he tells her that his kaalgat perskes (lit. naked peaches; nectarines) "blow kisses" at her! And in a final twist in this encounter across the colour line the vendor offers her "his guavas that are good for the nerves". Here Small unmasks the foolishness of injustice and dehumanisation, and the unsustainability thereof. Humour provides sustenance in a time of suffering and turns racial subjugation into power, just as it ensures that the current evil does not have absolute power. The implication is that this evil will be conquered.

In "Kô, lat ons sing" ("Come, let us sing") he suggests that music can be used as instrument of prophetic criticism and protest against the status quo and in service of a transformed society (Kitaar 11-12). Just as the staff in the hands of Moses, according to the Exodus 2 narrative, stands in service of liberation, what we have in our hands, what we have at our avail, can become instruments of liberation and transformation. Prophetic speaking according to Small, prompts concrete, courageous action. In the poem "Waar is Moses?" ("Where is Moses?") the narrator explains that Moses reprimanded his people, yet he also walked with them, led them out of slavery and that they were protected by God who was present in the column of fire by night and cloud by day (Sê sjibbolet 60-61). Moses acted in an imperfect, but nevertheless in a divine manner: yet his speech defect and his rage, which led to murder, did not disqualify him as servant of God:

And Moses was a stutterer

yes, Moses was a stammerer

and Moses was a murderer

but God was in his every vein ${ }^{1}$ 
For Small not only the poets and intellectuals are prophets. In the poem "Wie's Hy?" ("Who is he?") he praises the poetry of grassroots people, people who walk in the street with brilliant speech and forms of expression, and who invokes God to act against the wrongs that they expose (Sê sjibbolet 70):

But you are the poets

you who walk in the street

[you] with the gift of the gab

who see [these] things

and on the spot call God down upon them!

These words of complaint, protest and criticism should be heard clearly in a context where so many injustices continue to exist. In democracies things can still go wrong. Despite the good progress that we are making as a nation, many wrongs still exist. We have one of the biggest gaps between rich and poor, high levels of unemployment, exclusion of millions from basic goods and services like healthcare, welfare, education, food, water and housing, violence and crime, corruption and nepotism, class and racism, misogyny and homophobia, greed and consumerism, oppression and marginalisation of the most vulnerable. We do not embody the vision of a new society of dignity and justice and freedom as yet. Whilst this is the case we need the courageous prophetic criticism of champions for justice like Adam Small.

\section{Prophetic policy-making}

Prophets impact on public discourses, public opinion-formation and public policymaking. Small's work continues to play a role in these processes. Even though he does not participate directly any longer, his legacy should be retrieved and applied to current public debates.

According to Gustafson $(43,46)$ policy discourse distinguishes itself from the other discourses in two ways: it is conducted by people who have the responsibility to make choices, and to carry out the actions that are required by those choices. Visionaries and critics can all function with the external perspective of an observer, but policymakers function with the internal perspective of persons and agents who are responsible to make choices in quite complex and specific circumstances that constrain their possible actions.

Laws are made to embody the vision of a good society. Laws are made to address the criticisms against so many wrongs in society. Without pretending to give blueprints for policies Small paved the way for the removal of apartheid policies and for the formulation and implementation of policies that would usher in a new society. His broader vision of a new society and his exposure of the wrongs of an old society provide benchmarks for contemporary policy-makers. 
In the poem "What about de lô?" ("What about the law?") he tells the story of a Coloured man, Martin, and a white woman Diana who fell in love. Since they were to be jailed for their transgression of apartheid policies they committed suicide (Kitaar 52-54). This tragedy makes Small asks questions about lawmaking that still inform our policymaking processes today: Questions on the legitimacy of laws for legality does not automatically imply legitimacy.

According to Dirkie Smit (343) Small poses questions about the legitimacy, the morality and the justice of apartheid policies. The poet, firstly seems to question the morality of the existing, the so-called positive law of the state that forbids the noble human expression of love across human boundaries like race (344-46). He, secondly seems to question the justice of a law that might be derived from the natural law tradition that seeks access to a universal understanding of justice through human nature and rational thought (346-47). He, thirdly, seems to hint at the relationship between law and faith. In this regard Smit (347-49) argues that Small might have in mind that from a faith perspective the relationship between law and justice, i.e. between reg en geregtigheid, can only be properly dealt with when their relationship with justification, with regverdiging, is considered.

Within this perspective themes that enter the discourse are the relationship between law and theology, law and faith, law and the gospel, justification and justice, divine justice and human justice. The reality of radical reversal through justification, grace, unconditional acceptance, forgiveness and radically new affirmation forms part of the discussion. Smit (349) concludes that he hears in Small's poems the voice of the Protestant theological tradition, specifically the Reformed tradition, where the implications of the gospel of salvation for life together, for law and for morality are seriously considered.

Small's poem reminds us that even though our laws in a secular state, or in a state that is neutral with respect to religious and secular worldviews, cannot be duplicates of religious laws, they need to be informed by the broad moral directives that we receive from various religious and secular traditions, i.e. human dignity, justice, freedom and equality.

\section{Conclusion}

The rich work of Adam Small is indeed prophetic work. It was prophetic during our struggle against apartheid, and it is prophetic in our quest to build a new society. He guides us to keep the vision and hope of a new society alive. He appeals to us not to forget the vision but to be encouraged, inspired and energised by that hopeful vision. He also calls on us to expose the wrongs in contemporary societies, to offer courageous criticism, especially since former champions of the former liberation movements are now governing, and even though societal wrongs are more difficult to describe than 
during apartheid. He challenges us to make sure that honest self-criticism remains part of our prophetic practice of criticism. And lastly, he provides guidelines for our participation in policy-making processes. He provides parameters for laws that are not only legal, but also legitimate, morally sound and just. Our quest for human dignity, for justice and freedom are well served by the prophetic voice of Adam Small.

\section{Notes}

1. “En Moses was 'n hakkelaar, / Dja Moses was 'n stamelaar / En Moses was 'n moordenaar, / Ma God was in sy elke aar -" (Sê sjibbolet 60-61). All translations are mine.

2. "Ma djúlle is die poets, / djulle wat in die straat in loep / Ennie gladde bek verkoep / Ma die dinge sien / En soema net da God tien hulle roep!" (Sê sjibbolet 70).

\section{Works Cited}

Alves, Rubem. Tomorrow's Child. Imagination, Creativity, and the Rebirth of Culture. New York, Evanston, San Francisco; London: Harper \& Row Publishers, 1972.

Boesak, Allan et al., eds. Dreaming a Different World. Globalisation and Justice for Humanity and the Earth. The Challenge of the Accra Confession for the Churches. N.p.: Uniting Reformed Church in Southern Africa and the Evangelisch Reformierte Kirche in Germany, 2010. < http://academic.sun.ac/tsv/>.

Gustafson, James. Varieties of Moral Discourse: Prophetic, Narrative, Ethical, and Policy. Stob Lectures of Calvin College and Seminary, Grand Rapids, 1988.

Küster, Volker. God. Terreur. Een Tweeluik. Vught: Uitgeverij Skandalon, 2008.

Small, Adam. "Blackness versus Nihilism." Essays on Black Theology. Ed. Mokgethi Motlhabi. Johannesburg: Black Theology Project of the University Christian Movement. 1972. 10-16.

—. Kitaar my kruis. 1962. $3^{\text {rd }}$ ed. Pretoria: Hollandsch Afrikaansche Uitgevers. 1975.

—. Sê sjibbolet. 1963. $2^{\text {nd }}$ ed. Johannesburg: Perskor-Uitgewery. 1978.

Smit, D. J. "Law and Morality? Some Theological Perspectives." Scriptura 101 (2009): 341-51. 